\title{
Look into the Future through the Past
}

\author{
Johannes Hebebrand $^{\mathrm{a}}$ Thorkild I.A. Sørensen ${ }^{\mathrm{b}}$ \\ ${ }^{a}$ Department of Child and Adolescent Psychiatry, University of Duisburg-Essen, Essen, Germany \\ ${ }^{\mathrm{b}}$ Institute of Preventive Medicine, Copenhagen University Hospital, Centre for Health and Society, Copenhagen, Denmark
}

Can we predict our future? This question has had a great appeal for mankind; from antiquity until the present we have resorted to prophecies or omens in hope of determining what tomorrow has in store. Some of us lay cards, others look into the stars, and still others stare into crystal balls. So, is it possible to get a glimpse of the future? Scientists typically say no. This no has, however, not stopped scientists from laying the groundwork for prediction of specific outcomes.

Obviously, phenomena that in the past have shown considerable stability over a long time period are very likely to remain stable in the future. Body weight appears to be such a phenomenon. Those in a particular adult population who are the most obese are likely to have been the most obese in the past and be the most obese later on. On the other hand, it is only a likelihood, implying that a fraction of the obese individuals at any one point in time were not obese in the past or will not be obese in the future. The longer the time span between the baseline and follow-up assessment the larger this fraction becomes.

Tracking is the tendency for the individual to maintain his/ her position with regard to a particular categorical or dimensional phenotype over time relative to other members of the same population. Tracking of weight category or BMI can accordingly be defined as a tendency to maintain under-, normal or overweight or relative position such as BMI decile as defined via a reference population over time.

The trajectory may largely be accounted for by the tracking tendency of body weight, implying that its main determinants are also exhibiting a parallel tracking over time. Heritability estimates of BMI in twin studies have proven to be largely independent of age (excluding infancy) pointing to a prominent role of genetic factors and gene-environment interactions in both tracking and in deviations from an original trajectory. This first special issue of OBEsity FACTs looks at various aspects of tracking, and hence provides hints about how successful we may be in this particular aspect of our future trajectory.

Many studies have been conducted to examine tracking of height and BMI from infancy and childhood into adulthood, for example on the basis of the British national birth cohorts $[1,2]$. In the US study by Guo et al. [3], the correlation coefficients between BMI at age 35 years and childhood BMI at 1,10 and 18 years were approximately $0.15,0.5$ and 0.7 based on 555 white probands; correlations for females tended to be somewhat higher than for males. Both newborn length and weight adjusted for gestational age and parental height and BMI explained BMI variance in adolescence in a large Finnish study of 4,376 16-year-old Finnish twin adolescents [4]; for every kilogram at birth, adolescent BMI was on average $0.5 \mathrm{~kg} / \mathrm{m}^{2}$ higher. In male participants of the Harvard Longitudinal Studies of Child Health and Development, BMI at age 50 proved to be correlated with BMI at $18(\mathrm{r}=0.51), 30(\mathrm{r}=$ $0.74)$ and $40(\mathrm{r}=0.77)$ years [5]; the respective correlations for females were $0.44,0.80$, and 0.87 . The degree of obesity in the parents has a strong influence on the tracking level of their obese children, and those who have two obese parents show a stronger tracking tendency than those without obese parents [2]. In conclusion, your current BMI pretty well predicts that you will find yourself in a similar position if you rank your BMI in relationship to that of your friends in 5 years from now. If you are young, you may look forward to some change in 25 years from now.

What are the main determinants of tracking? Tracking is usually assessed within a relatively homogeneous environment which, despite changing over time, nevertheless stays similar for all individuals of the respective group or population. Obviously, moving to a very different environment entails that tracking in relationship to the former reference age group should decline. Tracking is also dependent on staying healthy; many somatic and psychiatric disorders and their pharmacological treatment can alter body weight. Taking up or stopping smoking will also impact tracking, as will some lifestyle choices which can have a partially hereditary basis.

Obviously, DNA variation in the genes is important as the key biological structure that remains the same throughout life. However, the genes relevant for weight regulation are apparently not the same throughout life; presumably epige-

\section{KARGER}

Fax +497614520714

Information@Karger.de

www.karger.com (c) 2009 S. Karger GmbH, Freiburg

Accessible online at:

www.karger.com/ofa
Prof. Dr. Johannes Hebebran

Department of Child and Adolescent Psychiatry

University of Duisburg-Essen

Virchowstraße 174, 45147 Essen, Germany

Tel: +49 201 7227-465, Fax -302

johannes.hebebrand@uni-due.de 
netic factors lead to alterations in expression levels of specific gene variants with an influence on BMI. According to a large longitudinal twin study, only $40 \%$ of the genetic factors that influence BMI at age 20 in males continue to do so at age 48; apparently after this age the same genes remain operative [6]. Some of the recently identified polygenes $[7,8]$ exert an effect on BMI during both childhood and adulthood. According to López-Bermejo et al. [9], genetic variation at the FTO gene already exerts in effect on body weight in 2-week-old Spanish infants. However, in another substantially larger Finnish study the FTO genotype did not influence BMI in children younger than 7 years of age [10]. On the other hand, the FTO gene may continue to exert its effect on body mass through adulthood [11]. A SNP at the 3' prime end of the melanocortin-4 receptor gene $(M C 4 R)$ has been shown to have no effect on BMI of children aged 0-7 years. In late childhood, the effect size of this variant was shown to exceed that observed during adulthood [12]; the variant had an influence on height in adults only. Single novel variants have been identified that seemingly influence BMI in adulthood only, such as MTCH2 und SH2B1 [13]. As more polygenes involved in weight regulation are detected, our knowledge of the extent to which each of these variants influences BMI across the age span will increase.

Conceivably, the combination of alleles involved in weight regulation specific to a healthy individual together with environmental factors that may have induced permanent modifications in the genes (persistent epigenetics) are important determinants of the individual tracking position. Stability over time in concurrently operating environmental factors may also contribute to the tracking tendency, but the complexity of the role of the genes is illustrated by the findings in twin studies (see below) that there are genes in which variations make the individuals particularly susceptible to changes in the environment, and hence may lead to departure from the tracking level.

For this special issue of OBEsITy FACTS we have invited internationally renowned experts in the field of tracking. Two author groups were asked to contribute papers dealing with tracking of BMI from early life into adulthood [14] and to provide an overview of the genetic aspects of this phenomenon [15]. Two additional articles examine tracking of food intake [16] and whether fat intake predicts weight gain [17]. This is complemented by a review of tracking of physical activity from childhood to adulthood [18]. The final two articles pertain to older individuals and health issues. Thus, Fuemmeler et al. [19] address the prediction of later adult-onset cancers in relationship to growth patterns during childhood and adolescence. Finally, Bales and Buhr [20] examine the extent to which obesity might actually be associated with better health in old age.

\section{Tracking of $B M I$}

Craigie et al. [14] followed-up 111 female and 84 male subjects aged 12 in 1979-1981 21 years later. In accordance with previ- ous studies (see above), BMI at the two time points was correlated $(\mathrm{r} \approx 0.55)$; BMI at age 12 was also correlated to a similar extent with waist circumference at age 33 . Obesity in adolescence tracked well into adulthood and predicted central obesity $(\mathrm{r} \approx 0.6)$. Based on a PubMed search for all studies that had analyzed the genetic component behind the longitudinal change of BMI, Silventoinen and Kaprio [15] identified 5 genetically orientated longitudinal studies on childhood obesity and 8 on obesity in adulthood ( 9 twin, 3 family and 1 adoption studies). Studies from birth or childhood to age 18 typically show a genetic correlation between BMI at ages 1 and $18(\mathrm{r} \approx 0.3)$ and increase steadily the older the child, indicating that there is a strong genetic continuity in BMI from childhood to onset of adulthood. A substantial common environmental factor was also detected in some of the respective studies, which was however weaker than the genetic factor. (Interestingly, twin studies on BMI have typically detected mainly an influence of non-shared environment.) Published twin studies have shown substantial heritability of BMI change in adulthood, varying from 0.57 to 0.86 using different measures of change, varying statistical models, and variable follow-up times. In parallel with the situation in formal genetic studies addressing heritability of BMI, family studies have yielded lower estimates.

\section{Tracking of Dietary Intake}

Both tracking of energy intake and expenditure can conceivably account for tracking of body weight. However, whereas height and weight can readily be measured precisely over time, this is not the case for parameters of energy intake and expenditure. Based on the same sample (total $n=198$ ) Craigie et al. [14] analyzed to assess tracking of BMI, Lake et al. [16] analyzed two 3-day food diaries collected in 1980 and 2000 in addition to demographic and socio-economic information; foods consumed were assigned to the five categories in the Balance of Good Health (BGH) food model. Overall, intake of fruits and vegetables increased during this time period, intake of foods with fat and/or sugar decreased as well as of milk and dairy products. Significant correlations between 1980 and 2000 were detected for bread, other cereals, potatoes, fruits and vegetables, meat, fish and alternatives. However, tracking was low (correlations ranged from $r=0.16$ to 0.26 ). Thus, although participants' intake of these foods increased between 1980 and 2000 , they tended to maintain their position in the distribution of intakes. Sub-analyses found different correlations based on i) gender and ii) location of the participants in the year 2000 relative to the original location of the study in Northhumberland and Tyne. Most studies that aimed to identify a relationship between childhood fat intake and subsequent weight development achieved negative results. Brixval et al. [17] make no exception: No relationship of fat intake at baseline in children aged 9-10 and subsequent weight change after 6 years was found. Only BMI z-score at baseline predicted weight change in both males and females. For the girls, the number of obese parents had a significant relation to weight change. 


\section{Tracking of Physical Activity}

Telama [18] reviewed studies on the tracking of physical activity in all phases of life from childhood to late adulthood, only few of which were published prior to 2000. Similar to studies pertaining to energy intake, methodological problems are inherent to studies that assess tracking of physical activity levels. Thus, only a small proportion of the studies had based their measurements on objective methods. Median follow-up duration was 9 years. Gender is important: Low to moderate tracking of physical activity was observed in males during all life phases and even in long-term follow-up studies. In contrast, tracking in females was either low or non-existent. Among both sexes tracking seems to be somewhat lower in early childhood than in adolescence or in adulthood, and lower in transitional phases, such as from childhood to adolescence or from adolescence to adulthood, than in adulthood. Telama [18] concludes that, when taking into account the different methods used for estimating habitual physical activity and the failure to control for important covariates in studies of tracking, physical activity appears to track reasonably well; this even applies in the longer term.

\section{Tracking and Risk of Cancer in Later Adulthood}

The mechanisms by which weight, diet, and physical activity influence tumor formation and progression are not well understood. Based on a systematic PubMed research, Fuemmeler et al. [19] review a large set of epidemiologic studies examining childhood and adolescent weight, diet, and physical activity as they relate to risk of adulthood cancers; methodological issues are obviously important and particularly include whether or not weight and height were measured (or recalled) during childhood and adolescence. Interesting findings can be summarized as follows: In most studies a greater BMI at age 18 , or higher perceived body fat relative to others during childhood, was found to be associated with an approximately $20-50 \%$ decreased risk of breast cancer. For ovarian and endometrial cancer, there is evidence to indicate that a higher BMI during adolescence predicts an increased risk. Similarly, overweight and obesity in adolescence entail a higher risk for colon cancer. Several studies have linked physical inactivity in adulthood to elevated cancer risk; whether or not activity levels during childhood and adolescence have an independent effect is viewed controversially. Some studies have found an independent beneficial effect of physical activity in adolescence for breast cancer. Disentangling current from past diet behavior also poses a challenge. Single studies have indicated an influence of childhood and adolescent diet composition on cancer risk. As Fuemmeler et al. [19] point out, the major limitation of all studies is recall accuracy of foods consumed decades ago; limiting recall to a narrower time window, or focused only on the intake of a particular food, further affects this limitation.

\section{Obesity in Old Age: Good or Bad?}

Bales and Buhr [20] address this controversial topic in a review focusing on BMI as a determinant of mortality and of health status and of health impact of weight reduction in the elderly. Epidemiological studies have found an inverse relationship between obesity in old age and mortality. However, a range of studies has shown beneficial health effects upon intended weight loss in the elderly. The authors conclude that optimal body mass may vary in the same person over time and/or between individuals according to gender, body composition, ethnicity, and medical status. They recommend further studies to look into the relationship between late adult obesity and longevity and health status. Health services research on care delivery of the elderly obese is required.

The articles of the present issue show the importance of investigating tracking of obesity, and they also demonstrate that there is much to be learned from advancing this field. As long as there are individual differences within our populations, it makes sense to investigate tracking with long-term longitudinal studies in which both obesity measures and putative determinants are assessed repeatedly over time and analyzed by statistical methods that can capture the tracking phenomenon and identify and quantify its determinants. The unspoken assumption of most obesity research is that body weight may change over time with or without explicit interventions, upwards or downwards, the former creating our problems and the latter our hope for solutions.

\section{References}

1 Power C, Lake JK, Cole TJ: Body mass index and height from childhood to adult life in the 1958 British birth cohort. Am J Clin Nutr 1997;66:10941101

2 Lake JK, Power C, Cole TJ: Child to adult body mass index in the 1958 British birth cohort: associations with parental obesity. Arch Dis Child 1997;77:376-381.

3 Guo SS, Roche AF, Chumlea WC, Gardner JD, Siervogel RM: The predictive value of childhood body mass index values for overweight at age $35 \mathrm{y}$. Am J Clin Nutr 1994;59:810-819.
4 Pietiläinen KH, Kaprio J, Räsänen M, Winter T, Rissanen A, Rose RJ. Tracking of body size from birth to late adolescence: contributions of birth length, birth weight, duration of gestation, parents' body size, and twinship. Am J Epidemiol 2001;154:21-29.

5 Casey VA, Dwyer JT, Coleman KA, Valadian I: Body mass index from childhood to middle age: a 50-year follow-up. Am J Clin Nutr 1992;56:14-18.

6 Fabsitz RR, Carmelli D, Hewitt JK: Evidence for independent genetic influences on obesity in middle age. Int J Obes Relat Metab Disord 1992;16: 657-666.
7 Hinney A, Hebebrand J: Polygenic obesity in humans. Obes Facts 2008;1:35-42.

8 Hinney A, Hebebrand J: Three at one swoop! Obes Facts 2009;2:3-8.

9 López-Bermejo A, Petry CJ, Díaz M, Sebastiani G, de Zegher F, Dunger DB, Ibáñez L: The association between the FTO gene and fat mass in humans develops by the postnatal age of two weeks. J Clin Endocrinol Metable 2008;93:1501-1505 
10 Hakanen M, Raitakari OT, Lehtimäki T, Peltonen N, Pahkala K, Sillanmäki L, Lagström H, Viikari J, Simell O, Rönnemaa T: FTO genotype is associated with body mass index after the age of seven years but not with energy intake or leisuretime physical activity. J Clin Endocrinol Metable 2009;94:1281-1287.

11 Jess T, Zimmermann E, Kring SI, Berentzen T, Holst C, Toubro S, Astrup A, Hansen T, Pedersen $\mathrm{O}$, Sørensen TI: Impact on weight dynamics and general growth of the common FTO rs9939609: a longitudinal Danish cohort study. Int J Obes (Lond) 2008;32:1388-1394.

12 Loos RJ, Lindgren CM, Li S, Wheeler E, Zhao JH, Prokopenko I, Inouye M, Freathy RM, Attwood AP, Beckmann JS, Berndt SI; Prostate, Lung, Colorectal, and Ovarian (PLCO) Cancer Screening Trial; Jacobs KB, Chanock SJ, Hayes RB, Bergmann S, Bennett AJ, Bingham SA, Bochud M, Brown M, Cauchi S, Connell JM, Cooper C, Smith GD, Day I, Dina C, De S, Dermitzakis ET, Doney AS, Elliott KS, Elliott P, Evans DM, Sadaf Farooqi I, Froguel P, Ghori J, Groves CJ, Gwilliam R, Hadley D, Hall AS, Hattersley AT, Hebebrand J, Heid IM; KORA, Lamina C, Gieger C, Illig T, Meitinger T, Wichmann HE, Herrera B, Hinney A, Hunt SE, Jarvelin MR, Johnson T, Jolley JD, Karpe F, Keniry A, Khaw KT, Luben RN, Mangino M, Marchini J, McArdle WL, McGinnis R, Meyre D, Munroe PB, Morris AD, Ness AR, Neville MJ, Nica AC, Ong KK, O'Rahilly S, Owen KR, Palmer CN, Papadakis K, Potter S, Pouta A, Qi L, Nurses' Health Study; Randall JC, Rayner NW, Ring SM, Sandhu MS, Scherag A, Sims MA, Song K, Soranzo N, Speliotes EK, Diabetes Genetics Initiative; Syddal HE, Teichmann SA, Timpson NJ, Tobias JH, Uda M; SardiNIA Study, Vogel CI, Wallace C, Waterworth DM, Weedon MN, Wellcome Trust Case Control Consortium; Willer CJ; FUSION; Wraight, Yuan X, Zeggini E, Hirschhorn JN, Strachan DP, Ouwehand WH, Caulfield MJ, Samani NJ, Fray- ling TM, Vollenweider P, Waeber G, Mooser V, Deloukas P, McCarthy MI, Wareham NJ, Barroso I, Jacobs KB, Chanock SJ, Hayes RB, Lamina C, Gieger C, Illig T, Meitinger T, Wichmann HE, Kraft P, Hankinson SE, Hunter DJ, Hu FB, Lyon HN, Voight BF, Ridderstrale M, Groop L, Scheet P, Sanna S, Abecasis GR, Albai G, Nagaraja R, Schlessinger D, Jackson AU, Tuomilehto J, Collins FS, Boehnke M, Mohlke KL: Common variants near MC4R are associated with fat mass, weight and risk of obesity. Nat Genet 2008;40:768-775.

13 Willer CJ, Speliotes EK, Loos RJ, Li S, Lindgren CM, Heid IM, Berndt SI, Elliott AL, Jackson AU, Lamina C, Lettre G, Lim N, Lyon HN, McCarroll SA, Papadakis K, Qi L, Randall JC, Roccasecca RM, Sanna S, Scheet P, Weedon MN, Wheeler E, Zhao JH, Jacobs LC, Prokopenko I, Soranzo N, Tanaka T, Timpson NJ, Almgren P, Bennett A, Bergman RN, Bingham SA, Bonnycastle LL, Brown M, Burtt NP, Chines P, Coin L, Collins FS, Connell JM, Cooper C, Smith GD, Dennison EM, Deodhar P, Elliott P, Erdos MR, Estrada K, Evans DM, Gianniny L, Gieger C, Gillson CJ, Guiducci C, Hackett R, Hadley D, Hall AS, Havulinna AS, Hebebrand J, Hofman A, Isomaa B, Jacobs KB, Johnson T, Jousilahti P, Jovanovic Z, Khaw KT, Kraft P, Kuokkanen M, Kuusisto J, Laitinen J, Lakatta EG, Luan J, Luben RN, Mangino M, McArdle WL, Meitinger T, Mulas A, Munroe PB, Narisu N, Ness AR, Northstone K, O'Rahilly S, Purmann C, Rees MG, Ridderstråle M, Ring SM, Rivadeneira F, Ruokonen A, Sandhu MS, Saramies J, Scott LJ, Scuteri A, Silander K, Sims MA, Song K, Stephens J, Stevens S, Stringham HM, Tung YC, Valle TT, Van Duijn CM, Vimaleswaran KS, Vollenweider P, Waeber G, Wallace C, Watanabe RM, Waterworth DM, Watkins N, Wellcome Trust Case Control Consortium; Witteman JC, Zeggini E, Zhai G, Zillikens MC, Altshuler D, Caulfield MJ, Chanock SJ, Farooqi IS, Ferrucci L, Guralnik JM, Hattersley AT, Hu FB, Jarvelin MR, Laakso M,
Mooser V, Ong KK, Ouwehand WH, Salomaa V, Samani NJ, Spector TD, Tuomi T, Tuomilehto J, Uda M, Uitterlinden AG, Wareham NJ, Deloukas P, Frayling TM, Groop LC, Hayes RB, Hunter DJ, Mohlke KL, Peltonen L, Schlessinger D, Strachan DP, Wichmann HE, McCarthy MI, Boehnke M, Barroso I, Abecasis GR, Hirschhorn JN, Genetic Investigation of ANthropometric Traits Consortium: Six new loci associated with body mass index highlight a neuronal influence on body weight regulation. Nat Genet 2009;4:25-34.

14 Craigie AM, Matthews JNS, Rugg-Gunn AJ, Lake AA, Mathers JC, Adamson AJ: Raised adolescent body mass index predicts the development of adiposity and a central distribution of body fat in adulthood: a longitudinal study. Obes Facts 2009; 2(3):150-156.

15 Silventoinen K, Kaprio J: Genetics of tracking of body mass index from birth to late middle age: evidence from twin and family studies. Obes Facts 2009;2(3):196-202.

16 Lake AA, Adamson AJ, Craigie AM, Rugg-Gunn AJ, Mathers JC: Tracking of dietary intake and predicting dietary change from early adolescence to adulthood: the ASH30 Study. Obes Facts 2009;2(3): 157-165.

17 Brixval C, Anderson LB, Lilienthal Heitmann B Fat intake and weight development from 9 to 16 years of age: the European Youth Heart Study - a longitudinal study. Obes Facts 2009;2(3):166-170.

18 Telama R: Tracking of physical activity from childhood to adulthood. Obes Facts 2009;2(3):187-195.

19 Fuemmeler BF, Pendzich MK, Tercyak KP: Weight, dietary behavior, and physical activity in childhood and adolescence: implications for adult cancer risk. Obes Facts 2009;2(3):179-186.

20 Bales CW, Buhr GT: Body mass trajectory and energy balance as determinants of health and mortality in older adults. Obes Facts 2009;2(3):171-178. 